\title{
Vegetation structure and spatial heterogeneity in the Granite Supersite, Kruger National Park
}

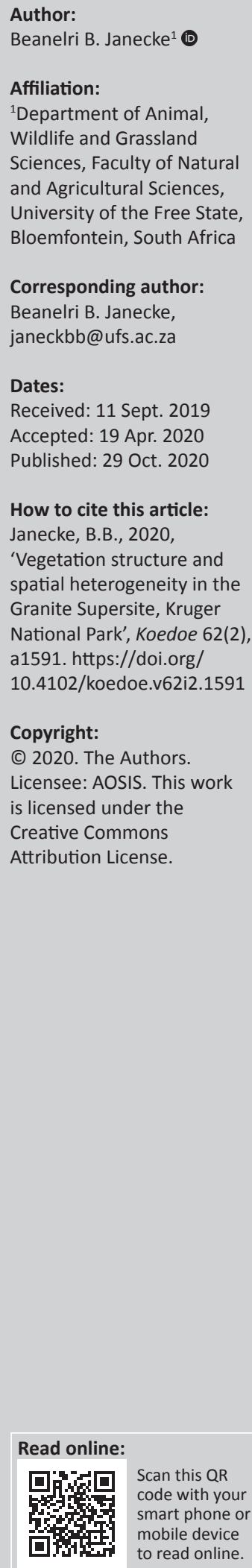

Spatial heterogeneity is the unequal distribution of landscape features and consists of diversity in vegetation structure, number and size of woody plants, patchiness in grass cover, subcanopy habitats, etc. A granite catena (hillslope) comprises of a gradient of soils, hydrology patterns and vegetation composition, creating a spatially heterogeneous area with variety in animal habitats. Objectives were to determine small-scale spatial heterogeneity along a catena near Skukuza, such as vegetation structure, patchiness, size and cover of woody and grass components, to describe certain catenal processes. Tree sizes and canopy cover were measured and the point method used on seven $100 \mathrm{~m}$ transects representing different catenal zones. Grasses were categorised according to grazing value, ecological status and percentage shade tolerant grasses. A total of 155 tree canopies were present. Large trees $(>5 \mathrm{~m})$ occurred in riparian zone and upper midslope, but were low in number $(<4$ per transect). Woody plants ranged in number from 8 to 32, canopy cover $4.5 \%-33.6 \%$, and grass cover from $47 \%$ to $69 \%$ between zones. A strong correlation was found between canopy cover and shade-tolerant grasses. Size of sub-canopy habitats are mostly determined by size of woody plants and both are important to animals. Various factors related to vegetation contributed to heterogeneity and spatial stratification patterns of the catena ecosystem.

Conservation implications: Concerns about the decline in tree numbers inside Kruger National Park are addressed. Mammal habitats and plant communities are impacted by the decline. The research can be linked to the long-term exclosure studies on granites at Nkuhlu.

Keywords: Big trees; Drought; Grazers and browsers; Savanna; Sodic grazing lawn.

\section{Introduction}

Spatial patterns in plant communities, including vegetation structure, patchiness and density, as well as the factors that generate them, have been receiving increased attention from ecologists (Adjorlolo \& Mutanga 2013; Eckhardt, Wilgen \& Biggs 2000; Gordijn, Rice \& Ward 2012; Holdo 2007; Lévesque \& King 2003; Murwira \& Skidmore 2006). Spatial heterogeneity refers to the unequal dissemination of a landscape or population in a specific area (Khan et al. 2019). According to Khan et al. (2019):

A landscape with spatial heterogeneity [sic] for example, is composed of concentrations of numerous biological species of plant or animal origin, terrain formations (geological) or environmental attributes (e.g. rainfall, temperature, wind) included in the area. (p. 127)

Several spatially stratified heterogeneous phenomena can be described, such as vertical layering of plants in an environment; differences in population densities between areas, ecological zones or climates; and distribution of soil types, land cover and land use (Pickett, Cadenasso \& Benning 2003; Wang, Zhang \& Fu 2016). A landscape with savanna components (e.g. trees, shrubs, grasses and forbs) that occurs on different soil types along an environmental gradient, such as a catena, can thus be considered as a spatially heterogeneous area.

Local spatial patterning forms part of the description of spatial heterogeneity and is associated with alternation between vegetated and bare areas that commonly occur in savanna systems. This variability and patchiness of vegetation cover creates different habitats for wildlife species (Augustine 2003, Murwira \& Skidmore 2006). Khomo and Rogers (2005:30) describe the patchiness of a granite catena (hillslope with different soil and hydrology gradients) specifically as a 'spatio-temporally complex boundary' between footslope and upland vegetation. In addition, small-scale patch structure can also be observed in plant species distribution and vertical layering,

Note: Special Issue: Connections between abiotic and biotic components of a granite catena ecosystem in Kruger National Park, sub-edited by Beanelri Janecke and Johan van Tol. 
where pattern diversity can indicate the dissimilarity in species composition of areas within the same sward (Augustine 2003; McNaughton 1983). The extent of woody vegetation cover is determined at a regional scale largely by precipitation and climate (Sankaran et al. 2005), while on a landscape scale, cover and vegetation structure are determined by topography, fire, herbivory, geological substrate, etc. (Asner et al. 2009; Holdo 2007; Sankaran, Ratnam \& Hanan 2008; Venter, Scholes \& Eckhardt 2003). Two of the primary determinants of savanna dynamics, namely, herbivory and fire, have both a strong and opposing effect on spatial pattern diversity (Augustine 2003).

Vegetation structure and plant species composition play an important role in the suitability of a habitat to animals. This is because different animal species are sensitive to the size of vegetated and bare patches in the landscape, and this makes the state of the spatial heterogeneity (i.e. patchiness) a valuable indicator of the suitability of a habitat to animals (Turner 1989). It is easy to distinguish between grass plains, tree savannas, forests and thickets on the basis of the structure of their vegetation. Within a specific habitat, there are also differences in the vegetation structure, like between shortgrass and tall-grass plains (Venter et al. 2003). Vegetation structure can change seasonally (deciduous nature of woody plants), through animal impact, or when fire burns away tall grasses to convert the area to a short-grass area (Bond 2008; Gordijn et al. 2012; Holdo 2007; Janecke \& Smit 2011; Joubert 2016). On the individual tree scale, it is known that savanna trees have positive and negative (competition) effects on grasses growing below their canopies relative to grasses in inter-canopy areas. Thus, large trees can affect plant species composition in sub-canopy areas and therefore change the vegetation structure of that immediate environment (Riginos et al. 2009; Treydte et al. 2007). Some of the positive effects of large trees and shrubs on the environment include enriched nutrients in soil and grass leaves in sub-canopy areas, increased soil water availability because of hydraulic lift, reduced evapotranspiration and increased grass productivity (Riginos et al. 2009). Large woody plants provide animals with shade, shelter against climate conditions, food for browsing animals, sub-habitats with higher nutrient levels, higher yield of highly palatable grass species and many more rewards (Smit \& Swart 1994; Treydte, Riginos \& Jeltsch 2010; Treydte et al. 2007).

Many savanna systems across the world have undergone some dramatic changes in terms of tree abundance (Bond 2008). In some areas, trees and shrubs are increasing in density because of encroachment into open areas, while in other areas woody plant densities are declining mostly because of elephant impact and heavy browsing and grazing, which in turn reduces the fuel load for fires (Grant et al. 2011; Riginos et al. 2009). This upsets the delicate balance between trees and grasses in a normal savanna system and can change the vegetation structure and species composition (Riginos et al. 2009).

Adjorlolo and Mutanga (2013:305) mentioned that managers in Kruger National Park (KNP) use a series of monitoring endpoints or 'thresholds of potential concern' (TPCs) to define limits of changes in biodiversity and vegetation structure that are acceptable. The TPCs for woody vegetation cover or density in landscape groups of KNP should not drop more than $80 \%$ of the maximum value and the mean drop for the entire park should not exceed 30\% (Gillson \& Duffin 2007). It is important to determine woody density or canopy cover in order to develop an early warning system that can guide management to identify landscapes with possible TPC (Adjorlolo \& Mutanga 2013). Many studies focus on largescale surveys that require expensive technology and expert knowledge (i.e. Leckie et al. 2003; Lévesque \& King 2003; Murwira \& Skidmore 2006), but small-scale studies on vegetation structure and direct measurement of vegetation can also have importance in determining local areas where changes in vegetation structure and cover are taking place (Buitenwerf, Swemmer \& Peel 2011; Ludwig et al. 1999; O'Connor 1998; Peel, Kruger \& Zacharias 2005).

The granite landscape in the south of KNP is finely dissected with a high density of streams and hillslopes or catenas (Smit et al. 2013). These catenas each have a soil sequence arranged in zones with different soil properties and soil types from the crest to the footslope (Weil \& Brady), but each soil type occurs on the underlying granite. The various slopes facilitate transfer of different particles from upslope areas down the hills along an environmental gradient that results in variation in the soil and its associated vegetation in the different zones on each hillslope (Khomo et al. 2011). The catena ecosystem thus consists of abiotic and biotic processes that play a part in its normal functioning. The environmental gradient along the catenas creates heterogeneity in the landscape, while the topo-edaphic differences also support different vegetation structure and plant cover in the catenal zones.

Soil, hydrology and vegetation form the foundation of the catena ecosystem; therefore, it is important to give an accurate description of these. This study forms part of a bigger study presented in this Special Issue where multidisciplinary research fields are focussed on the same local study area (small area) with the ultimate goal of finding links and processes that can drive the catena functioning. The multidisciplinary research has been conducted on a small scale to provide a basis for further studies in the same area, or to be expanded to the larger Southern Granite Supersite, or to be used as comparison for similar studies.

This study is an extension of the vegetation studies that formed part of the multidisciplinary research and expands on the description of plant communities along the environmental gradient (from top to bottom of the hillslope) done in the study area (Theron et al. 2020). The focus of this study was not on large-scale spatial patterning, where remote sensing, georeferencing or Light Detection and Ranging (LiDAR) techniques are usually used, but rather on local small-scale patterns, structure and heterogeneity of a specific area. The aims of this study were to determine spatial heterogeneity in (1) the general vegetation structure (including the number and size of woody plants and their 
canopies) and vegetation cover in each catenal zone in order to (2) describe the small-scale patterns and patchiness of woody and herbaceous vegetation along a specific granite catena, and also to (3) refer to some of the processes where vegetation structure and patterning or cover play a part in the functioning of this ecosystem. These aspects are important when describing the habitat of mammals and the catena environment. Because of the different zones present from the crest to the drainage line of the catena, the expectations were high to find differences along this catenal gradient in vegetation structure, plant cover and the consequent vegetation patterns that form along the hillslope.

\section{Methods}

\section{Study area}

Supersites were established in 2013 to give researchers an opportunity to focus research geographically in specific areas of KNP and to allow long-term monitoring and integration of data across different research themes on specific large study areas with similar climate and geology (Smit et al. 2013). One of the four identified supersites is located in the StevensonHamilton area on a granite landscape $\left(\sim 36 \mathrm{~km}^{2}\right)($ Smit 2020 ; Smit et al. 2013). This study was conducted on a part of this supersite located between $25^{\circ} 06^{\prime} 28.6 \mathrm{~S}, 31^{\circ} 34^{\prime} 41.9 \mathrm{E}$ and $25^{\circ} 06^{\prime} 25.7 \mathrm{~S}, 31^{\circ} 34^{\prime} 33.7 \mathrm{E}$, approximately $10 \mathrm{~km}$ from Skukuza. The supersite falls in the Renosterkoppies land type of the Savanna Biome, described as a transitional area between land types associated with the catchment of the Sabie River (Smit et al. 2013).

The study focussed on one catena (or hillslope) from the crest down to the third order drainage line (or watercourse) in the Sabie River catchment. A Global Positioning System (GPS) was used to indicate the highest point ( $370 \mathrm{~m}$ above sea level [m.a.s.1.]) that was taken as the crest. The lowest point was inside the drainage line at $354 \mathrm{~m}$ m.a.s.l. It is not a steep slope $(1 \%)$, with a gradual drop of $16 \mathrm{~m}$ over a $200 \mathrm{~m}$ length. A seepline was present in the transitional area between the upper midslope and the sodic patch on the lower midslope. This formed a green grass belt that could clearly be differentiated from the rest of the sodic patch during the time of study. The riparian zone contained a small floodplain and the banks of the drainage line. Jacobs and Naiman (2008) reported vegetation types and zones similar to what was found in this study. Research for our study was conducted in the same area where previous soil studies and geohydrology were performed (Riddell et al. 2020).

The vegetation on the hillslopes is generally described as moderately dense bush or shrub savanna, with a riverine forest at the valley bottom in areas closer to the river (Smit et al. 2013). Vegetation classification of the specific study area was done by Theron, Van Aardt and Du Preez (2020). They recorded a cover abundance of 171 plant species and also included a visual illustration of this catena. Smit et al. (2013) reported that the average herbaceous biomass was $2900 \mathrm{~kg} / \mathrm{ha}$ and woody cover was $45 \%$ for the supersite. Combretum apiculatum and Combretum zeyheri mostly dominate the sandy crests of catenas in this supersite. Clayey midslopes and footslopes are dominated by fine-leaved woody species, such as Vachellia nilotica. Euclea divinorum characterises the footslopes where duplex, sodic soils occur (Smit et al. 2013). A vegetation description of a similar granite catena closer to the perennial Sabie River is provided by Siebert and Eckhardt (2008), and the effect of fire and herbivory by Van Coller, Siebert and Siebert (2013).

\section{Vegetation surveys}

The study followed on the vegetation classification surveys (description of plant communities) that were conducted as part of a bigger multidisciplinary research project in the same study area during 2015. Line transects of this study were placed in the length of the catenal zones, in other words, perpendicular to the single long belt transect that ran from the crest down to the drainage line, that was used for the description of the vegetation gradient from top to bottom of the catena by Theron et al. (2020). In this way, the vegetation structure and cover of each zone could be described separately in this study. Seven line transects of $3.5 \mathrm{~m} \times 100 \mathrm{~m}$ were spaced roughly $25 \mathrm{~m}$ apart from the crest to the drainage line to represent the four catenal zones identified during our veld survey. These zones were identified based on their position on the catena and their associated plant community, namely, crest and upper midslope, lower midslope or sodic patch, footslope shrub veld and a riparian zone around the dry drainage line.

Two measurements were taken to describe the canopy of trees and shrubs, where crown refers to an individual plant and canopy refers to more crowns together in the same area. The first measurement was taken for the widest part of the crown (if the largest part of that crown fell inside the transect). This was done to describe maximum crown width of individual plants. An adapted Biomass Estimates of Canopy Volume (BECVOL) method (Smit 2014) was used where only the height and width of the broadest or widest part of the crown were measured for woody plants rooted inside the transect (trunk present inside the transect) (Leverett \& Bertolette n.d.). These woody species located inside the transect were identified on a species basis and counted. The second canopy measurement was taken for only the part of the canopy that covered the $100 \mathrm{~m}$ measuring tape. This was done to describe canopy cover. A $100 \mathrm{~m}$ measuring tape was positioned in the centre of the transect and the part of the crown that covered the tape was measured, irrespective of whether the trunk was present in the transect or not. Canopy cover is defined as the proportion of a fixed area on the ground that was covered by woody plant crowns (Jennings, Brown \& Sheil 1999). The dead trees were only included as an observation at the end of the study period and no further data were collected on them. Trees were regarded as large if they were more than $5 \mathrm{~m}$ tall, medium if they were $3 \mathrm{~m}-4 \mathrm{~m}$ tall and small if they were $<1 \mathrm{~m}-2 \mathrm{~m}$ tall. 
The point method was used to determine grass cover and species composition (Evans \& Love 1957; Owensby 1973). At each metre mark of the measuring tape, a metal rod was positioned (100 points). If the base or crown and/or shoot of a grass tuft touched the rod, it was noted as such. If no grass shoot was touched by the metal rod (open area), the nearest grass ( $30 \mathrm{~cm}$ radius) was noted, and if no grass was within the radius, it was noted as bare soil. Grasses were identified up to species level. Forbs were not included in this study, but forb cover (percentage class values) on a species basis was recorded by Theron et al. (2020) for the study area. The grass cover was determined at the end of the growing season during 2015 and repeated in 2016 on the exact locations, based on GPS positions of the transects. Because of the drought in 2016 and consequent intense grazing of available grass by herbivores, grass species were very difficult to identify and living (green) grasses were rather grouped based on the size of their tufts as follows: small tuft $(<3 \mathrm{~cm}$ across, $1 \mathrm{~cm}-2 \mathrm{~cm}$ high with no seed culms or leaves), short tuft $(<10 \mathrm{~cm}$ across, up to $3 \mathrm{~cm}$ high with few leaves but no seed culms), medium tuft ( $5 \mathrm{~cm}-10 \mathrm{~cm}$ high with leaves) and tall tuft $(30 \mathrm{~cm}$ and higher with leaves and/or seed culms in some unpalatable species). Normally, dead plants are not recorded with this method, but to indicate the impact of the drought, the percentage of dead grasses was noted during 2016.

\section{Data and statistical analyses}

Woody plants were grouped into different height classes based on about $1 \mathrm{~m}$ increments, that is, $0 \mathrm{~m}-0.9 \mathrm{~m}, 1 \mathrm{~m}$ $1.9 \mathrm{~m}, 2 \mathrm{~m}-2.9 \mathrm{~m}$, etc., up to $5 \mathrm{~m}$ and then the trees higher than $5 \mathrm{~m}$ were grouped together for each transect. The number of species per transect, as well as the number of individual woody plants for each height class, was counted and tabulated. A difference was made between rooted woody plants where the trunk was within the transect $(3.5 \mathrm{~m} \times$ $100 \mathrm{~m}$ ) and woody plants that were not rooted in the transect but their canopies covered part of the transect. Similar size classes were used for categorising the maximum crown width of woody plants (where the broadest part was measured). This differs from the more commonly used average crown spread where the longest and shortest extent of the crown is measured and divided by two (Blozan 2006). The number of woody plants that fall in a crown width class was indicated on a stack bar graph for each transect. The percentage area covered by the canopies was determined by the sum total of each part of a crown that covered the $100 \mathrm{~m}$ tape measure in a transect. The number of woody canopies that covered the tape measure was counted per size class (maximum crown width), although they were not necessarily rooted in the transect.

The number of points where a grass tuft (crown or shoot) touched the metal rod with the point method (hits) was totalled to indicate the grass cover of living grasses, while points with 'no hit' were divided into nearest grass $(30 \mathrm{~cm}$ radius) and bare soil (with no grass present in a $30 \mathrm{~cm}$ radius of the rod). Grass species were grouped into different categories based on their grazing value, plant succession stage and ecological status, following Van Oudshoorn (2012) and Roodt (2015). The percentage of each grass species in a category (determined from the number of points where the species touched the rod out of 100 points in total) was summarised in a table for each transect. The percentage of grass species known to grow in shade (like under tree canopies) was also totalled per transect. These grasses were Panicum maximum, Setaria verticillata, Sporobolus fimbriatus and Urochloa mosambicensis. Pearson's correlation coefficient (calculated from Stangroom 2019) was used to indicate the linear relationship between the percentage canopy cover and percentage shade grasses (grass species hit and nearest grasses/no hit with point method) on the same $100 \mathrm{~m}$ line in each transect. The Shapiro-Wilk test was performed separately on the number of grass tuft hits and the nearest grass values (excluding the bare soil) of 2015 and 2016 to test for normality. The data were normally distributed and the one-tailed $t$-test for independent variables was performed at $5 \%$ level (Stangroom 2019) to test for differences in grass cover between the two years.

\section{Ethical considerations}

Ethical approval for the multidisciplinary project as a whole was obtained from the Interfaculty Animal Ethics Committee at the University of the Free State (UFS-AED2019/0121).

\section{Results \\ Description of the tree layer}

A total number of 155 woody plant canopies partially covered the seven transects (Table 1), while 137 of those plants were also rooted inside the transects (trunk included). An average

TABLE 1: Numbers of individual woody plants and woody species present in each transect $(3.5 \mathrm{~m} \times 100 \mathrm{~m})$. The total number of woody plants indicates all individuals where the crown only, or crown and trunk (rooted), was within the transect. Canopy cover and the number of plants directly on the line were indicated for all woody species where the crown covered the $100 \mathrm{~m}$ measuring tape. The number of grass species and percentage of grasses that grow in the shade, determined by hits of the point method on the $100 \mathrm{~m}$ line, are also indicated.

\begin{tabular}{|c|c|c|c|c|c|c|}
\hline Catenal zone & $\begin{array}{l}\text { Total nr woody plants } \\
\text { in transect }\end{array}$ & $\begin{array}{l}\text { Nr woody species } \\
\text { in transect }\end{array}$ & $\begin{array}{l}\mathrm{Nr} \text { woody plants } \\
\text { on } 100 \mathrm{~m} \text { line }\end{array}$ & $\begin{array}{l}\text { Canopy cover (\%) } \\
\text { on } 100 \mathrm{~m} \text { line }\end{array}$ & $\begin{array}{l}\mathrm{Nr} \text { of grass species } \\
\text { on } 100 \mathrm{~m} \text { line }\end{array}$ & $\begin{array}{l}\text { Shade grasses (\%) } \\
\text { on } 100 \mathrm{~m} \text { line }\end{array}$ \\
\hline Crest & 26 & 9 & 14 & 17.9 & 15 & 28 \\
\hline Upper midslope & 23 & 8 & 10 & 10.5 & 16 & 26 \\
\hline Above sodic site & 25 & 12 & 8 & 21.5 & 12 & 45 \\
\hline Upper sodic site & 10 & 6 & 5 & 4.5 & 7 & 18 \\
\hline Lower sodic site & 8 & 6 & 3 & 2.7 & 9 & 20 \\
\hline Shrub veld & 31 & 12 & 13 & 17.5 & 8 & 39 \\
\hline Riparian zone & 32 & 13 & 11 & 33.6 & 11 & 55 \\
\hline
\end{tabular}


of 21 rooted woody plants per transect was recorded on the upper midslope, nine woody plants in the sodic patch, a total of 31 rooted plants in the footslope shrub veld and 26 plants in the riparian area. The number of woody species (crown inside transect) is shown in Table 1. The transitional area between the upper midslope and the sodic patch on the lower midslope, next to the seepline, had a higher number of woody species present relative to the other zones (see transect 'Above sodic site' in Table 1). Note that this does not include all the woody plant diversity present in each catenal zone for a complete description of the vegetation, the species composition and its correlation with soil properties in the study area, see Theron et al. (2020).

All height classes of the woody plants (from $<1 \mathrm{~m}$ to $>5 \mathrm{~m}$ ) were represented on the crest and upper midslope of the catena (Figure 1). The largest trees ( $>5 \mathrm{~m}$ high) were found at the drainage line in the riparian zone and a high number of large trees occurred on the upper midslope just above the sodic patch seepline, but only a low number of smaller woody plants ( $<2 \mathrm{~m}$ high) were present on the sodic patch itself. The shrub veld transect passed through a patch of Pterocarpus rotundifolius, with more than 31 small trees in the patch $(<1 \mathrm{~m}$ high because of browsing by animals). Nine of the 20 small plants $(<2 \mathrm{~m})$ indicated as total for that size class are from this patch (Figure 1).

The maximum crown width of individual woody plants that were grouped into the mentioned size classes is indicated in Figure 2. Only one or two trees had a maximum crown width of $4.0 \mathrm{~m}-4.9 \mathrm{~m}$ in each catenal zone, excluding the sodic patch on the lower midslope, while three to four individual trees had a maximum crown width of larger than $5 \mathrm{~m}$ (Figure 2). The low number of trees and shrubs present in the sodic patch accounted for the low percentage canopy cover $(2.7 \%-4.5 \%)$ (Table 1$)$. The highest percentage cover was found in the riparian zone, followed by the above sodic transitional area and the crest (Table 1). In these three mentioned areas, the highest numbers of larger trees $(>4 \mathrm{~m})$ were also present (Figure 1).

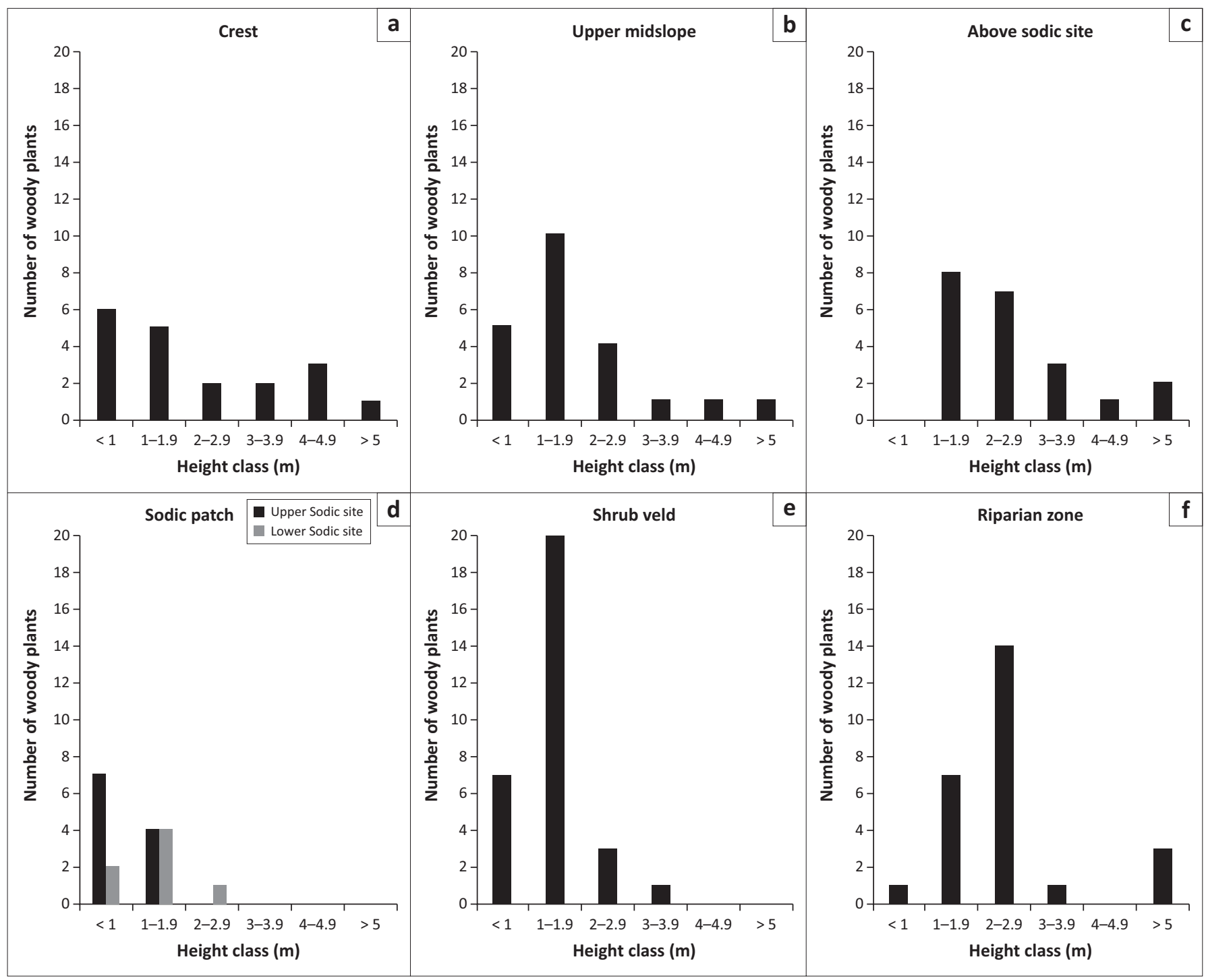

FIGURE 1: The number of woody plants (different species) in each height class for a transect that represents the following catenal zones: (a) crest, (b) upper midslope, (c) above sodic site, (d) sodic patch, (e) shrub veld and (f) riparian zone in the granite study area. The sodic patch was divided into an upper and a lower site, but both are indicated separately on the same graph. 


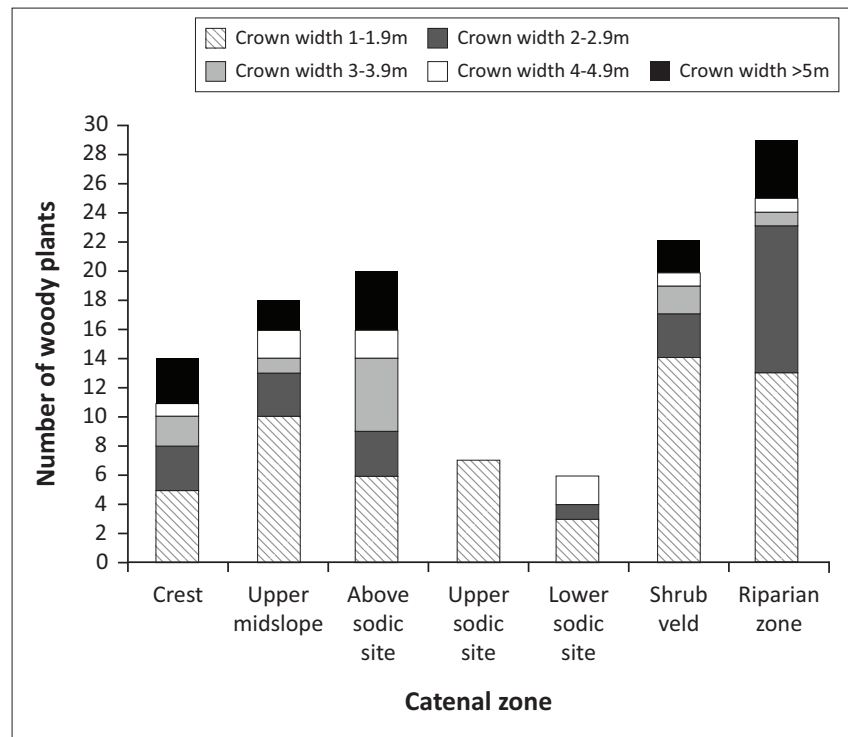

FIGURE 2: The numbers of woody plants with maximum crown width in a specific size range are indicated for each transect that represents a catenal zone.

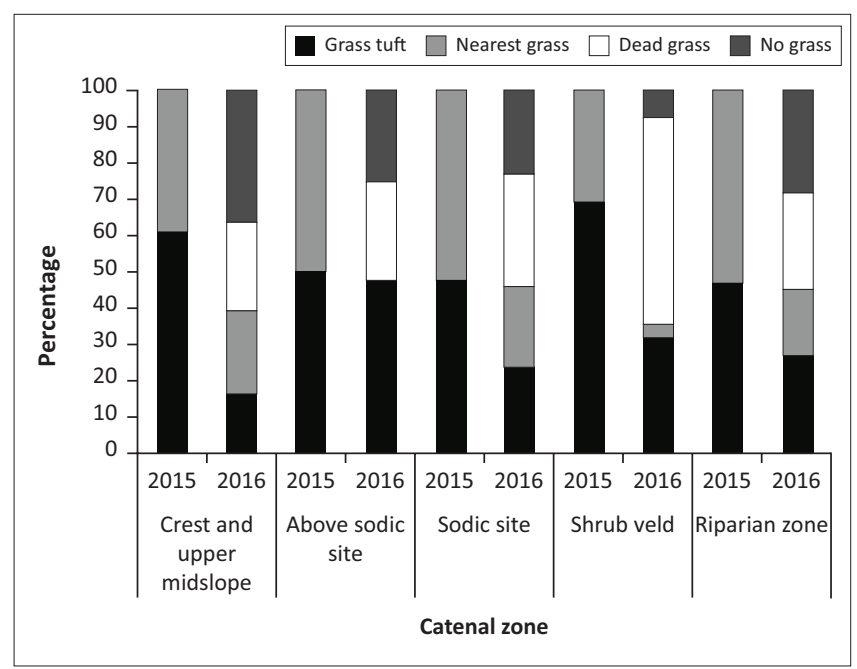

FIGURE 3: Comparison between two years of grass cover in the exact same locations in each catenal zone. It is based on point method data on a $100 \mathrm{~m}$ line transect. If the crown (base) or shoot of a grass tuft was touched by a metal rod, it was indicated as grass cover. If no tuft was touched by the rod, the nearest grass ( $30 \mathrm{~cm}$ radius) was noted, and if no living grass was within the radius, it was noted as bare soil or dead grass, respectively. No grass was noted as bare soil or dead grass, respectively. Forbs were not included.

\section{Description of the grass layer}

Grass cover ranged from 47\% to 69\% during 2015 in different catenal zones of the study area, with the lowest cover in the riparian zone on the banks of the dry drainage line and on the lower midslope sodic site (Figure 3). Although no bare soil per se was indicated in the results for 2015, the 'Nearest Grass' percentages represented open areas where no grass was touched by the metal rod of the point method. Larger bare areas were visible on the drainage line banks and in the sodic patch that fell outside the transect line used for vegetation surveys and was thus not reflected in the percentages of the results. Significant differences were observed in grass cover between the two years of surveys (Grass Tufts hit: $t=6.08$, $p=0.0001$; and Nearest Grass: $t=4.58, p=0.0009$ ) and the percentage bare patches increased during the second year of drought to such an extent that it was clearly visible in the results of 2016 (Figure 3). It became difficult to identify grass species during the drought in the fixed transects because of the majority of grass tufts that were grazed to stubble height $(<5 \mathrm{~cm}$; Table 2).

About $58 \%-74 \%$ of the grass species present on the upper midslope transects during 2015 were of high grazing value (Table 3), with $37 \%-38 \%$ of the species in transects on the sodic area and $60 \%-76 \%$ in the riparian area and shrub veld classified as high grazing value species. The dominant grasses present in the sodic patch transects were of average to high grazing value, but that does not indicate the effect of the nutrients in the soil on the acceptability or palatability of the grasses. The categorisation of grass species differs between areas and one species does not always fall in the same ecological status or successional category in different regions because of differences in climate and soil nutrients (Roodt 2015). However, in general, most of these grass species mentioned (Table 3) are also decreasers (that decrease with overgrazing because of high acceptability and selection by herbivores) and climax species (that are the perennial, better-adapted, top species in the order of plant succession) based on the classification of Van Oudtshoorn (2012). The numbers of grass species recorded in each line transect (including Nearest Grass percentages) and the percentage of those grasses (hits with the point method) that are known to grow in shade are presented in Table 1.

\section{Discussion}

A catena is a dynamic arrangement of vegetation and localised soils in a gradient pattern resulting from geological features, hydrology and topography that cause apparent irregularities in vegetation distribution (Emmet \& Pattrick 2012). This gradient creates different catenal zones that are responsible for spatial heterogeneity on the catena, for example, in different structures of the vegetation in each zone, the varying plant cover and resulting alternating patches of vegetated and bare areas, among others (Wang et al. 2016). Woody plants increase the spatial heterogeneity of the plant community because they occur in different heights (vertical layering) and canopy sizes, and because they create sub-canopy environments where certain herbaceous species can flourish (Treydte et al. 2010). Woody plants concentrate nutrients and water in sub-canopy environments and increase animal diversity by providing forage to herbivores and by providing protection to herbivores and predators from the harsh climate of the savanna (Belsky 1994). Animal presence can lead to changes in vegetation structure and patterning in the savanna.

A total of 137 individual woody plants were rooted in the seven transects covering the four catenal zones during the vegetation survey. Several trees were uprooted by elephants (Loxodonta africana) and most of these trees died in the two years of drought following the vegetation survey, possibly as a result of the combined effect of the drought and elephants (pers. obs. October 2016 \& April 2017). The loss of 
TABLE 2: Percentage of grass tufts of a certain size touched by the metal rod (hit) of the point method (100 points per line) at the end of the growing season of 2016, during the drought. The percentage of dead grass and bare soil (no hit) was also included.

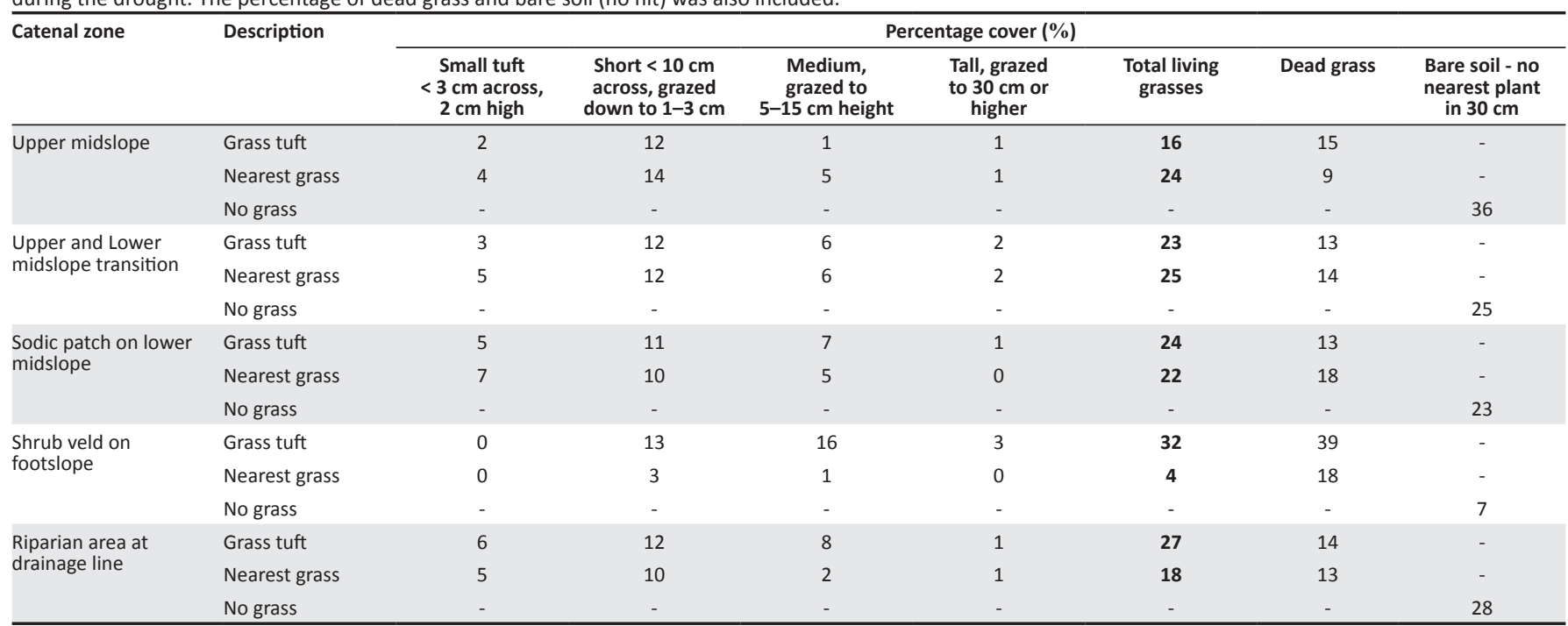

TABLE 3: Contribution (\%) of grass species present on $100 \mathrm{~m}$ point method line to different categories for each catenal zone.

\begin{tabular}{|c|c|c|c|c|c|c|c|c|c|c|}
\hline Catenal zone & $\begin{array}{c}\text { Grazing value } \\
\text { Low }(\%)\end{array}$ & $\begin{array}{l}\text { Grazing value } \\
\text { Average }\end{array}$ & $\begin{array}{c}\text { Grazing value } \\
\text { High }\end{array}$ & Decreaser & Increaser I & Increaser II & Increaser III & Pioneer & Subclimax & Climax \\
\hline Crest & 26 & 7 & 67 & 66 & 0 & 34 & 0 & 20 & 14 & 66 \\
\hline Upper midslope & 39 & 3 & 58 & 57 & 1 & 40 & 2 & 12 & 27 & 61 \\
\hline Above sodic site & 26 & 0 & 74 & 70 & 0 & 26 & 4 & 8 & 18 & 74 \\
\hline Upper sodic site & 17 & 45 & 38 & 1 & 0 & 99 & 0 & 74 & 25 & 1 \\
\hline Lower sodic site & 21 & 42 & 37 & 2 & 0 & 98 & 0 & 57 & 24 & 19 \\
\hline Shrub veld & 16 & 8 & 76 & 72 & 13 & 15 & 0 & 0 & 15 & 85 \\
\hline Riparian zone & 19 & 21 & 60 & 48 & 0 & 52 & 0 & 32 & 20 & 48 \\
\hline
\end{tabular}

trees did not form part of the scope of this study and no data are available on the number of trees that were affected, but it explains changes in the vegetation structure and spatial heterogeneity of the area and is therefore included as observations. Uprooting and breaking of trees by elephants alter the tree crown and change species composition and distribution of biomass (Pickett et al. 2003). Some of the bigger trees in the study area had clearly visible browse lines. Signs of browsing (probably from elephant) were also evident on all the small $P$. rotundifolius trees in a patch located in the shrub veld next to the riparian zone during 2015 - every tree in this patch was browsed and pruned to $1 \mathrm{~m}$ or less in height. During 2016, many of these small to large trees that showed significant damage by elephants have died (pers. obs. October 2016). Shannon et al. (2008) reported that $60 \%$ of large trees in the southern section of KNP exhibited utilisation by elephants and $4 \%$ were dead because of this animal's foraging behaviour. This might also provide an explanation to the low number of large trees in the study area and thus lower the spatial heterogeneity (as the large tree component is limited in the environment). The clear evidence of browsing by different browsers and of elephant foraging in the study area can be part of the reasons for the low number of large trees present. Other factors such as drought, tree competition, water availability and plant diseases might also play a role. The observations of treefall in the study area indicate a decline in the number of trees, especially in the medium $(3 \mathrm{~m}-4 \mathrm{~m})$ to large $(4 \mathrm{~m}-5 \mathrm{~m})$ height classes, and also in other height classes, over a period of two years.

There have been some concerns from conservationists and researchers about the general decline in the number of trees inside KNP over the past 50 - 75 years, especially in the large tree component (> $5 \mathrm{~m}$ tall) (Druce et al. 2008; Eckhardt et al. 2000; Levick \& Asner 2013; Shannon et al. 2008). The decline is believed to be mainly the result of an interaction between regular fires and utilisation by elephants; however, other factors such as rainfall and soil fertility can also play a role (Eckhardt et al. 2000; Sankaran et al. 2008; Whyte, Van Aarde \& Pimm 2003). As the current study cannot provide results on these factors mentioned because it falls outside the scope of the study, the following explanation on numbers of large trees in KNP and possible causes for low numbers is included from the literature. Eckhardt et al. (2000) stated that the density of large trees decreased by an estimated 15\%, while the smaller trees and shrubs increased in cover on the granites of the park between 1940 and 1998. Levick and Asner (2013) reported for the larger granitic catchment of the Sabie River (of which the study area forms a part) a rate of treefall loss of $20 \%$ in the $5 \mathrm{~m}$ height class specifically over two years. The treefall rate was not evenly distributed across different height classes in the landscape, but was the highest in the $4 \mathrm{~m}-6 \mathrm{~m}$ class, because these trees escaped the fire trap of $1 m-3 m$ but were still within the reach of elephants (Levick \& Asner 2013). The regular, frequent burning that is practised in the 
park will prevent smaller trees to develop into large trees, especially when combined with browsing (Eckhardt et al. 2000; Gordijn et al. 2012). The mean fire return interval for the Granite Supersite is reported to be 5.8 years, with the minimum interval being 1.04 years and the maximum interval being 11.05 years (Smit et al. 2013). Although some remnants of a previous fire were visible in a specific local area in the riparian zone of the study area, no fire went through the area during the study period. Our results confirmed that mostly smaller trees were present on the granite catena. Therefore, fire cannot be the main reason for the low numbers of large trees in the study area. The shallow depth of the soil in the sodic patch, the underlying rock bed and changes in soil hydrology of the catena because of the drought (Bouwer, Le Roux \& Van Tol 2020; Janecke et al. 2020; Khomo \& Rogers 2005), together with the visible impact of elephants, may have an influence on the number of trees that can survive in the study area.

Large trees might be low in numbers in the study area, but woody cover in general seems to be increasing on the granite catenas over time and that may change the vegetation structure normally associated with these areas. Eckhardt et al. (2000) reported that the increase in overall woody plant density $(12 \%)$ on the granites might be because of reduced competition from grasses as a result of overgrazing by herbivores. Intense grazing was especially obvious in the study area during the extreme drought of 2016 compared to the previous year (Figure 3). Heavy grazing of certain areas more than other areas creates patchiness that adds to spatial heterogeneity. The number of herbivores is usually high in most areas where surface drinking water is provided to them on a permanent basis (Grant et al. 2011; Shannon et al. 2008), and there are three permanent waterholes in close vicinity to the study area, which can lead to higher numbers of herbivores grazing in the areas surveyed. The average herbivore biomass on the Granite Supersite was reported to be $2.1 \mathrm{~kg}$ grazers $/ \mathrm{ha}, 3.0 \mathrm{~kg}$ browsers $/ \mathrm{ha}$ and $9.9 \mathrm{~kg}$ mixed feeders/ha (Smit et al. 2013). The herbivore species and numbers observed in the study area are listed by Janecke and Bolton (2020). In contrast, a decrease in woody cover was observed in the basalts, which is ascribed to the short-interval prescribed burning of those areas in combination with grazing. The density of grazing animals is usually higher on basalts than on granites, but the grasses on the nutrient-rich basalts can also recover better than those on the nutrientpoor granites after heavy grazing (Eckhardt et al. 2000). Whyte et al. (2003) reported a $64 \%$ decline in cover on basalts because of a $38 \%$ decrease in large trees $(>5 \mathrm{~m})$. Thus, different processes and causes are leading to changes in the woody cover and numbers of large woody plants between granites and basalts in KNP.

Herbivores have a definite effect on spatial patterns involving vegetation structure, diversity and cover (Augustine 2003). Van Coller et al. (2013) confirmed that the lowest herbaceous diversity occurred in the absence of all herbivores (after 10 years of animal exclusion) in the Nkuhlu long-term exclusion experiment in KNP and that herbivores are essential to sustain the richness of plant species in sodic areas. In the control site of the exclosures, the mean biomass was $1200 \mathrm{~kg} / \mathrm{ha}$ on the sodic site and $2700 \mathrm{~kg} / \mathrm{ha}$ in the exclosure where no animals or fire were present (Van Coller et al. 2013). Jacobs and Naiman (2008) reported a significant increase in mean herbaceous biomass in the riparian area of the Nkuhlu exclosures, located $18 \mathrm{~km}$ downstream of Skukuza on the northern bank of Sabie River, where animals are completely excluded from the area. Riparian areas in savannas are normally grazed extensively because herbivores are attracted by abundant grass forage, especially in the dry season (Du Toit 2003; Naiman \& Rogers 1997). These studies confirmed that herbivores have both a positive (higher herbaceous diversity in grazed areas) and a negative (intense grazing removing palatable grasses and biomass) impact on the catena, especially on the sodic site.

Canopy cover creates patchiness in the environment in the form of sub-habitats, each with its own microclimate underneath the canopy, and areas that are not covered (Jennings et al. 1999; Treydte et al. 2007). Large trees are important for the vegetation structure and provide many benefits to the environment. Isolated savanna trees can trigger vegetation heterogeneity by changing resource availability in their immediate surroundings and thus improve the herbaceous layer's growing conditions (Treydte et al. 2011). Some very large trees can produce shade up to $11 \mathrm{~m}$ away from the tree trunk (Belsky 1994; Treydte et al. 2010). In savanna with its high temperatures, shade is important for survival of many animals (Treydte et al. 2010). The canopy also affects light penetration and thus plant growth and survival, and this determines the type of vegetation growing under the canopy in the shaded areas (Jennings et al. 1999).

Canopy cover varied from $11 \%$ to $18 \%$ on the upper midslope transects, while $18 \%$ and $34 \%$ was calculated for the shrub veld and riparian zone transects, respectively (Table 1). This means that up to $34 \%$ of the riparian zone transects was under the canopies of woody plants and large areas were covered in shade. The riparian area specifically was characterised by large, trampled, open areas under the trees where animal droppings and tracks were found, indicating the extensive use of these areas possibly for shade. In the sodic patch, the lowest density of trees was observed compared to other catenal zones. Up to 14 plants per transect had a maximum crown width of less than $2 \mathrm{~m}$ on the catena, while less than five plants per transect had a maximum width of $3 \mathrm{~m}$ or more (Figure 2). The size of the woody plant's crown and its subsequent sub-habitat is important for the processes of nutrient cycling of the catena ecosystem (Janecke et al. 2020) because of the impact of the larger woody plants elevating nutrient levels and the animals using the larger sub-habitats while contributing with droppings. Scholes and Walker (1993) described spatial patterns of trees and shrubs at a scale of the plants themselves where canopies typically reach $3 m-6 m$ in both height and crown diameter, with an average canopy cover of $10 \%-40 \%$, but bigger trees are also 
known to occur in the Nylsvley area. These results corresponded to the results found in this study.

The composition of grass species usually differs significantly between canopied and open areas, thus affecting the vegetation structure and patterning (Riginos et al. 2009; Smit \& Swart 1994; Treydte et al. 2007). Elevated levels of grass leaf nitrogen and phosphorous were found underneath large tree canopies that were up to $25 \%$ higher than areas outside the canopies (Treydte et al. 2007). Treydte et al. (2010) reported that herbivores in the Satara area of KNP ate the grass and deposited dung twice as frequently beneath large and very large trees $(>7 \mathrm{~m})$ compared to open areas. This trend was not observed in smaller trees $(<2.5 \mathrm{~m})$. They concluded that large trees represent essential habitat features for herbivores and that small trees cannot provide the same functional or structural advantages as do large trees (Treydte et al. 2010). A strong positive correlation $(r=0.95, p=0.00098)$ was found between canopy cover (\%) of mostly the larger woody plants and shade-tolerant grasses (\%) in the current study. On the upper midslope of the study area, above the sodic site, shade grasses were present in $26 \%-45 \%$ of the hits by the point method (Table 1) and 39\% - 55\% in the shrub veld and riparian zone, respectively. This clearly indicated that if canopy cover decreased, as observed during the drought, the sub-canopy areas and the associated palatable grasses would also decrease. The general grazing value of the grasses found in the study area is indicated in Table 3. The abundance of high-quality grass species beneath trees usually attracts grazing animals (Treydte et al. 2007); thus, it is highly likely that lower availability of nutritious grasses will result in a decrease in grazer numbers on the upper midslope and riparian areas, which should also lead to higher use of the sodic areas with its higher nutrient levels than other areas of the catena.

Environmental conditions such as different soil properties in various areas, namely, wetness, leaching, clay or sand content, available nutrients, acidity $(\mathrm{pH})$, etc. (Bouwer et al. 2020; Khomo \& Rogers 2005), can influence nutrient content or palatability of plants. Sodic patches are known to contain soils with high levels of exchangeable sodium originating from sodium-releasing parent material such as granite (Bailey \& Scholes 1997; Khomo \& Rogers 2005), and it is a unique feature of semi-arid toposequences (Dye \& Walker 1980; Jacobs \& Naiman 2008). The presence of these patches on the catena contributes to its spatial heterogeneity by means of differences in plant species composition, vegetation structure (very few trees), distribution of soil types creating different vegetation zones, etc. Sodic patches are favoured by herbivores deriving essential nutrients from the plants growing there (Bailey \& Scholes 1997; Jacobs \& Naiman 2008). In the study area, most of the grasses were grouped into the pioneer and subclimax categories in the sodic area, indicating some form of disturbance. These sodic patches are commonly referred to as nutrient hotspots because of their high-quality forage (Grant \& Scholes 2006) and are also preferred by herbivores for higher predator visibility (Davidson et al. 2012). Most of these grass species present on the sodic patch were grouped into the average grazing value class (Table 3). In other words, these grasses are not normally classified as highly palatable decreaser species, but grasses growing on sodic patches and on termite mounds can be more nutritious than plants not growing on such enriched soils (Grant \& Scholes 2006), although this was not tested for in the current study. High percentages of grasses considered to have high grazing value were found in the upper midslope (74\%), shrub veld (76\%) and riparian zone $(60 \%)$.

The presence or absence of grasses contributes to vegetation cover and thus to the patchiness (bare and vegetated areas) associated with heterogeneity of the catena. Grass tufts provided cover to the soil during 2015, but in 2016 many tufts were dead, possibly as a result of extreme heat, low rainfall and animal grazing during the intensifying drought conditions (Table 2). The general lower presence of decreaser grass species in the sodic patch of this study area can be attributed to a combination of these reasons: it can be habitat specific (adapted grass species that grow in sodic conditions might not be decreaser species - see Bailey \& Scholes 1997; Theron et al. 2020); the near absence of trees might play a role (some of the palatable decreasers grow in shady conditions, or are associated with conditions in this kind of sub-habitat, Roodt 2015); or it might be because of higher grazing pressure based on the more nutrient-rich soils and wetter conditions of the sodic patches (because of the hydrology of the catena Bouwer et al. 2020); and the area might be slightly disturbed as well (Khomo \& Rogers 2005) because of high presence of animals (Janecke \& Bolton 2020).

A decline in grass cover was observed in the study area during the drought, mostly because of the climate and the impact of grazing on top of that, and this lowered the heterogeneity in the patchiness of the area by creating large bare areas and reducing vegetated areas. The effect of the drought (Van Aardt et al. 2020) could also clearly be seen in smaller grass tufts (Table 2) compared to the previous year's surveys. Statistically significant differences were observed between grass cover of 2015 and that of 2016 on transects in the same locations. Total herbaceous biomass in the sodic area of the Nkuhlu long-term exclusion experiment in KNP was also found to be low, which can be a reflection of the experienced drier conditions (less rainfall, but not drought conditions) throughout that study year, as well as the harsh growing conditions usually because of shallow surface soils and relatively impenetrable subsurface soils of the sodic areas (Dye \& Walker 1980; Van Coller et al. 2013). The study area can perhaps sustain herbivores for longer periods, as green vegetation was still available on the catena at the beginning of 2016, the second year of the drought, but not in the surrounding Skukuza area (Janecke et al. 2020).

Vegetation patchiness is common in the savannas and can be observed at specific scales, from landscape scale to individual tree or grass scale. A key driver of savanna ecosystem structure and functioning is the impact of large herbivores. Large herbivores alter standing biomass, woody and herbaceous diversity, and soil characteristics that form part 
of the heterogeneity in the structure of plant communities. Herbivory can also act as a disturbance by reducing the biomass and canopy cover of specific species and by increasing the spatial heterogeneity in the process (Jacobs \& Naiman 2008). Another well-known key driver of heterogeneity at a local scale is the tree-grass interaction that creates patchiness in vegetation cover (Colgan et al. 2012; Sankaran, Ratnam \& Hanan 2004). The structure of savannas is a result of several interacting factors that include climate, fire, resource competition, elephant foraging, grazing and browsing that usually operate at different spatial and temporal scales (Sankaran et al. 2004).

This study focussed on reporting the spatial heterogeneity of the catena vegetation structure and its patchy vegetation cover. Different zones are created on the catena because of soil types and characteristics that differ from the crest to the drainage line, and this causes alterations in plant species composition, vegetation structure and patterns in the zones. Vegetation structure ranged between the zones, from a high density of woody plants (including different height classes and crown widths) and a high grass cover to a low density of woody plants (where they were almost absent) and low grass cover. The number of woody plants in different height classes also differed between the upper midslope, sodic site, shrub veld and riparian zone, creating a variation in vertical layering on the catena. Patchiness was observed in alternating areas of different vegetation cover and bare areas that also led to certain patterns in the vegetation. Canopy cover increased the patterning and patchiness of vegetation by creating subhabitats under the canopies that differed from the intercanopy open areas. The drought caused changes in the distribution of patterns in the vegetation on the catena by increasing the bare areas to most of the catena, reducing the vegetated areas, and the spatial heterogeneity in the process. Herbivores (including elephants) can impact the observed spatial heterogeneity of the area by changing the vegetation structure and vertical layering (felling, removing and breaking woody plants), species composition and density (feeding more on palatable plants and opening up the vegetation), plant cover and patchiness (intensive grazing in higher nutritional areas and by trampling) and thus also impacting the patterns observed in the vegetation on the catena.

\section{Conclusions}

Spatial heterogeneity was found between the catenal zones as differences in the number of woody plants present, various sizes of trees and shrubs, grass cover (bare areas and vegetated areas), patchiness, sub-canopy habitats, etc. Large trees were scarce in the study area and mainly medium-tosmall woody plants were present in the vegetation structure. A positive correlation was found between canopy cover and the percentage of shade-tolerant grasses that impact subcanopy habitats and vegetation patchiness. Significant differences in grass cover were found between the two survey years, with larger bare areas noted in the drought year. Various factors from the literature that could have contributed to the heterogeneity and spatial stratification patterns of the catena ecosystem were mentioned. Some of these factors also play a role in the processes and functioning of the catena ecosystem, such as the nutrient cycling and the impact of animal presence on the habitat and sub-habitats created by the different vegetation structures. This smallscale vegetation structure study was used successfully to describe specific aspects of spatial heterogeneity on the catena and to provide information that can be used as a potential warning system for changes in vegetation structure with regard to specifically the low numbers of large trees. This data can be used by management as an indicator to identify when the study area will reach a Threshold of Potential Concern (TPC) for woody vegetation structure and cover.

\section{Acknowledgements}

The author wants to thank the late Fred Kruger from the Organisation for Tropical Studies and the Centre for Environmental Management at the University of the Free State for valuable input into this project and especially for his assistance with fieldwork for this article. The author would also like to thank the following persons and institutions: The University of the Free State Strategic Research Fund for largely funding the multi-disciplinary project; the National Research Foundation for partially funding the research in this article; the staff of SANParks Scientific Services for their friendliness and all the administrative arrangements; Martin Tinneveld (student) for field assistance; and Dr Tascha Vos for all her time and effort with table and figure formatting.

\section{Competing interests}

The author declares that she has no financial or personal relationships that may have inappropriately influenced her in writing this article.

\section{Author's contribution}

B.B.J. is the sole author of this research article.

\section{Funding information}

The University of the Free State Strategic Research Fund largely funded the multi-disciplinary project as a whole, including this part of the study, and the National Research Foundation Thuthuka Grant also partially funded this research.

\section{Data availability}

Data from all research done within Kruger National Park is placed within the SANParks repository (not for free, open access).

\section{Disclaimer}

The views and opinions expressed in this article are the author's own and do not necessarily reflect the official policy or position of the institution or funder. 


\section{References}

Adjorlolo, C. \& Mutanga, O., 2013, 'Integrating remote sensing and geostatistics to estimate woody vegetation in an African savanna', Journal of Spatial Science 58(2), 305-322. https://doi.org/10.1080/14498596.2013.815577

Asner, G.P., Levick, S.R., Kennedy-Bowdoin, T., Knapp, D.E., Emerson, R., Jacobson, J., et al., 2009, 'Large-scale impacts of herbivores on the structural diversity of African savannas', Proceedings of the National Academy of Sciences 106(12) 4947-4952. https://doi.org/10.1073/pnas.0810637106

Augustine, D.J., 2003, 'Spatial heterogeneity in the herbaceous layer of a semi-arid savanna ecosystem', Plant Ecology 167(2), 319-332. https://doi.org/10.1023/A: 1023927512590

Bailey, C.L. \& Scholes, M.C., 1997, 'Comparative patterns of sodium accumulation in leaves of selected savanna species growing on sodic and nonsodic soils', South African Journal of Plant and Soil 14(3), 103-106. https://doi.org/10.1080/025718 62.1997.10635090

Belsky, A.J., 1994, 'Influences of trees on savanna productivity: Tests of shade nutrients, and tree-grass competition', Ecology 75(4), 922-932. https://doi.org/ $10.2307 / 1939416$

Blozan, W., 2006, 'Tree measuring guidelines of the eastern native tree society', Bulletin of the Eastern Native Tree Society 1(1), 1-8.

Bond, W.J., 2008, 'What limits trees in C4 grasslands and savannas?', Annual Review of Ecology, Evolution and Systematics 39(1), 641-659. https://doi.org/10.1146/ annurev.ecolsys.39.110707.173411

Bouwer, D., Le Roux, P.A.L. \& Van Tol, J., 2020, 'Identification of hydropedological flowpaths in Stevenson-Hamilton catena from soil morphological, chemical and flowpaths in Stevenson-Hamilton catena from soil morphological, chemical and
hydraulic properties', Koedoe 62(2), a1584. https://doi.org/10.4102/koedoe. v62i2.1584

Buitenwerf, R., Swemmer, A.M. \& Peel, M.J.S., 2011, 'Long-term dynamics of herbaceous vegetation structure and composition in two African savanna reserves: Effects of rainfall on herbaceous vegetation', Journal of Applied Ecology 48(1), 238-246. https://doi.org/10.1111/j.1365-2664.2010.01895.x

Colgan, M.S., Asner, G.P., Levick, S.R., Martin, R.E. \& Chadwick, O.A., 2012, 'Topoedaphic controls over woody plant biomass in South African savannas', Biogeosciences 9(5), 1809-1821. https://doi.org/10.5194/bg-9-1809-2012

Davidson, Z., Valeix, M., Loveridge, A.J., Hunt, J.E., Johnson, P.J., Madzikanda, H. et al., 2012, 'Environmental determinants of habitat and kill site selection in a large carnivore: Scale matters', Journal of Mammalogy 93(3), 677-685. https://doi. org/10.1644/10-MAMM-A-424.1

Druce, D.J., Shannon, G., Page, B.R., Grant, R. \& Slotow, R., 2008, 'Ecological thresholds in the savanna landscape: Developing a protocol for monitoring the change in composition and utilisation of large trees', PLoS One 3(12), 1-12. e3979. https:// doi.org/10.1371/journal.pone.0003979

Du Toit, J.T., 2003, 'Large herbivores and savanna heterogeneity', in J.T. Du Toit, K.H. Rogers \& H.C. Biggs (eds.), The Kruger experience: Ecology and management of savanna heterogeneity, pp. 292-309, Island Press, Washington, WA.

Dye, P.J. \& Walker, B.H., 1980, 'Vegetation-environment relations on sodic soils of 'Zimbabwe Rhodesia', The Journal of Ecology 68(2), 589-602. https://doi. Zimbabwe Rhodesia',
org/10.2307/2259424

Eckhardt, H.C., Wilgen, B.W. \& Biggs, H.C., 2000, 'Trends in woody vegetation cover in the Kruger National Park, South Africa, between 1940 and 1998', African Journal of Ecology 38(2), 108-115. https://doi.org/10.1046/j.1365-2028.2000.00217.x

Emmet, M. \& Pattrick, S., 2012, Game Ranger in your backpack: All-in-one interpretative guide to the lowveld, Briza Publications, Pretoria.

Evans, R.A. \& Love, R.M., 1957, 'The step-point method of sampling: A practical tool in range research', Journal of Range Management 10(5), 208-212. https://doi. org/10.2307/3894015

Gillson, L. \& Duffin, K.I., 2007, 'Thresholds of potential concern as benchmarks in the management of African savannahs', Philosophical Transactions of the Royal Society B: Biological Sciences 362(1478), 309-319. https://doi.org/10.1098/rstb. 2006.1988

Gordijn, P.J., Rice, E. \& Ward, D., 2012, 'The effects of fire on woody plant encroachment are exacerbated by succession of trees of decreased palatability', Perspectives in Plant Ecology, Evolution
doi.org/10.1016/j.ppees.2012.09.005

Grant, C.C. \& Scholes, M.C., 2006, 'The importance of nutrient hot-spots in the conservation and management of large wild mammalian herbivores in semi-arid savannas', Biological Conservation 130(3), 426-437. https://doi.org/10.1016/j. biocon.2006.01.004

Grant, R.C.C., Peel, M.J.S., Bezuidenhout, H. \& Grant, R., 2011, 'Evaluating herbivore management outcomes and associated vegetation impacts', Koedoe 53(2), 116-130. https://doi.org/10.4102/koedoe.v53i2.1008

Holdo, R.M., 2007, 'Elephants, fire, and frost can determine community structure and composition in Kalahari Woodlands', Ecological Applications 17(2), 558-568. https://doi.org/10.1890/05-1990

Jacobs, S.M. \& Naiman, R.J., 2008, 'Large African herbivores decrease herbaceous plant biomass while increasing plant species richness in a semi-arid savann toposequence', Journal of Arid Environments 72(6), 891-903. https://doi. org/10.1016/j.jaridenv.2007.11.015

Janecke, B.B. \& Bolton, J.G., 2020, 'Variation in mammal habitat and diversity affect heterogeneity and processes of granite catena', Koedoe 62(2), a1592. https://doi.org/10.4102/koedoe.v62i2.1592

Janecke, B.B. \& Smit, G.N., 2011, 'Phenology of woody plants in riverine thicket and its impact on browse availability to game species', African Journal of Range \& Forage Science 28(3), 139-148. https://doi.org/10.2989/10220119.2011.642075
Janecke, B.B., Van Tol, J., Smit, I.P.J., Van Aardt, A.C., Riddell, E.S., Seaman, M.T. et al., 2020, 'Biotic and abiotic connections on a granitic catena: Framework for multidisciplinary research', Koedoe 62(2), a1600. https://doi.org/10.4102/ multidisciplinary rese

Jennings, S., Brown, N.D. \& Sheil, D., 1999, 'Assessing forest canopies and understorey illumination: Canopy closure, canopy cover and other measures', Forestry 72(1), 59-74. https://doi.org/10.1093/forestry/72.1.59

Joubert, S.C.J., 2016, 'Animal behaviour', in J. du P. Bothma \& J.T. Du Toit (eds.), Game ranch management, pp. 385-392, Van Schaik Publishers, Pretoria.

Khan, S.U., Khan, I., Zhao, M., Khan, A.A. \& Ali, M.A.S., 2019, 'Valuation of ecosystem services using choice experiment with preference heterogeneity: A benefit transfer analysis across inland river basin', Science of the Total Environment 679 126-135. https://doi.org/10.1016/j.scitotenv.2019.05.049

Khomo, L., Hartshorn, A.S., Rogers, K.H. \& Chadwick, O.A., 2011, 'Impact of rainfall and topography on the distribution of clays and major cations in granitic catenas
of southern Africa', Catena 87(1), 119-128. https://doi.org/10.1016/j.catena. of southern
2011.05.017

Khomo, L.M. \& Rogers, K.H., 2005, 'Proposed mechanism for the origin of sodic patches in Kruger National Park, South Africa', African Journal of Ecology 43(1), 29-34. https://doi.org/10.1111/j.1365-2028.2004.00532.x

Leckie, D., Gougeon, F., Hill, D., Quinn, R., Armstrong, L. \& Shreenan, R., 2003 'Combined high-density LIDAR and multispectral imagery for individual tree crown analysis', Canadian Journal of Remote Sensing 29(5), 633-649. https://doi. org $/ 10.5589 / \mathrm{m} 03-024$

Leverett, B. \& Bertolette, D., n.d., Champion trees measuring guidelines handbook, viewed 28 November 2018, from https://www.americanforests.org/wp-content/ uploads/2014/12/AF-Tree-Measuring-Guidelines_LR.pdf.

Lévesque, J. \& King, D.J., 2003, 'Spatial analysis of radiometric fractions from highresolution multispectral imagery for modelling individual tree crown and forest canopy structure and health', Remote Sensing of Environment 84(4), 589-602. https://doi.org/10.1016/S0034-4257(02)00182-7

Levick, S.R. \& Asner, G.P., 2013, 'The rate and spatial pattern of treefall in a savanna landscape', Biological Conservation 157, 121-127. https://doi.org/10.1016/j. biocon.2012.07.009

Ludwig, J.A., Tongway, D.J., Eager, R.W., Williams, R.J. \& Cook, G.D., 1999, 'Fine-scale vegetation patches decline in size and cover with increasing rainfall in Australian savannas', Landscape Ecology 14(6), 557-566. https://doi.org/10.1023/A:100811 2122193

McNaughton, S.J., 1983, 'Serengeti grassland ecology: The role of composite environmental factors and contingency in community organization', Ecological Monographs 53(3), 291-320. https://doi.org/10.2307/1942533

Murwira, A. \& Skidmore, A.K., 2006, 'Monitoring change in the spatial heterogeneity of vegetation cover in an African savanna', International Journal of Remote Sensing 27(11), 2255-2269. https://doi.org/10.1080/01431160500396683

Naiman, R.J. \& Rogers, K.H., 1997, 'Large animals and system-level characteristics in river corridors', BioScience 47(8), 521-529. https://doi.org/10.2307/1313120

O'Connor, T.G., 1998, 'Impact of sustained drought on a semi-arid Colophospermum mopane savanna', African Journal of Range \& Forage Science 15(3), 83-91. https://doi.org/10.1080/10220119.1998.9647948

Owensby, C.E., 1973, 'Modified step-point system for botanical composition and basal cover estimates', Journal of Range Management 26(4), 302-303. https://doi.org/ $10.2307 / 3896585$

Peel, M.J.S., Kruger, J.M. \& Zacharias, P.J.K., 2005, 'Environmental and management determinants of vegetation state on protected areas in the eastern Lowveld of South Africa', African Journal of Ecology 43(4), 352-361. https://doi.org/10.1111/ j.1365-2028.2005.00590.x

Pickett, S.T.A., Cadenasso, M.L. \& Benning, T.L., 2003, 'Biotic and abiotic variability as key determinants of savanna heterogeneity at multiple spatiotemporal scales', in J.T. Du Toit, K.H. Rogers \& H.C. Biggs (eds.), The Kruger experience: Ecology and management of savanna heterogeneity, pp. 22-40, Island Press, Washington, WA.

Riddell, E.S., Nel, J.M., Van Tol, J., Fundisi, D., Jumbi, F., Van Niekerk, A. et al., 2020, 'Groundwater-surface water interactions in an ephemeral savanna catchment, Kruger National Park', Koedoe 62(2), a1583. https://doi.org/10.4102/koedoe. v62i 2.1583

Riginos, C., Grace, J.B., Augustine, D.J. \& Young, T.P., 2009, 'Local versus landscapescale effects of savanna trees on grasses', Journal of Ecology 97(6), 1337-1345. https://doi.org/10.1111/j.1365-2745.2009.01563.x

Roodt, V., 2015, Grasses and grazers of Botswana and the surrounding savanna, Struik Nature Publishers, Cape Town.

Sankaran, M., Hanan, N.P., Scholes, R.J., Ratnam, J., Augustine, D.J., Cade, B.S. et al., 2005, 'Determinants of woody cover in African savannas', Nature 438(7069), 846-849. https://doi.org/10.1038/nature04070

Sankaran, M., Ratnam, J. \& Hanan, N., 2008, 'Woody cover in African savannas: The role of resources, fire and herbivory', Global Ecology and Biogeography 17(2), 236-245. https://doi.org/10.1111/j.1466-8238.2007.00360.x

Sankaran, M., Ratnam, J. \& Hanan, N.P., 2004, 'Tree-grass coexistence in savannas revisited - insights from an examination of assumptions and mechanisms invoked in existing models', Ecology Letters 7(6), 480-490. https://doi.org/10.1111/j. 1461-0248.2004.00596.x

Scholes, R. \& Walker, B.H., 1993, An African savanna: Synthesis of the Nylsvley study, Cambridge University Press, Cambridge, NY

Shannon, G., Druce, D.J., Page, B.R., Eckhardt, H.C., Grant, R. \& Slotow, R., 2008, 'The utilization of large savanna trees by elephant in southern Kruger National 'Park', Journal of Tropical Ecology 24(3), 281-289. https://doi.org/10.4102/koedoe. v50i1.138 
Siebert, F. \& Eckhardt, H.C., 2008, 'The vegetation and floristics of the Nkhuhlu exclosures, Kruger National Park', Koedoe, 50(1), 126-144. https://doi. org/10.4102/koedoe.v50i1.138

Smit, G.N. \& Swart, J.S., 1994, 'The influence of leguminous and non-leguminous woody plants on the herbaceous layer and soil under varying competition regimes in mixed bushveld', African Journal of Range and Forage Science 11(1), 27-33. https://doi.org/10.1080/10220119.1994.9638350

Smit, I.P.J., 2020, 'Integrating multi-scaled and multi-disciplinary studies: A critical reflection on the Kruger National Park Research Supersites', Koedoe 62(2), a1586. https://doi.org/10.4102/koedoe.v62i2.1586

Smit, I.P.J., Riddell, E.S., Cullum, C. \& Petersen, R., 2013, 'Kruger National Park research supersites: Establishing long-term research sites for cross-disciplinary, multiscaled learning', Koedoe 55(1), Art. \#1107, 7 pages. https://doi.org/10.4102/koedoe. v55i1.1107

Smit, N., 2014, 'BECVOL 3: An expansion of the aboveground biomass quantification model for trees and shrubs to include the wood component', African Journal of Range \& Forage Science 31(2), 179-186. https://doi.org/10.2989/10220119. 2013.866161

Stangroom, J., 2019, 'Different statistical calculators, social science statistics', viewed 05 December 2019, from https://www.socscistatistics.com/tests/ pearson/default.aspx.

Theron, E.J., Van Aardt, A.C. \& Du Preez, P.J., 2020, 'Vegetation distribution along a granite catena, southern Kruger National Park', Koedoe 62(2), a1588. https://doi. org/10.4102/koedoe.v62i2.1588

Treydte, A.C., Heitkönig, I.M.A., Prins, H.H.T. \& Ludwig, F., 2007, 'Trees improve grass quality for herbivores in African savannas', Perspectives in Plant Ecology, Evolution and Systematics 8(4), 197-205. https://doi.org/10.1016/j.ppees.2007.03.001

Treydte, A.C., Riginos, C. \& Jeltsch, F., 2010, 'Enhanced use of beneath-canopy vegetation by grazing ungulates in African savannahs', Journal of Arid Environments 74(12), 1597-1603. https://doi.org/10.1016/j.jaridenv.2010.07.003
Treydte, A.C., Van Der Beek, J.G.M., Perdok, A.A. \& Van Wieren, S.E., 2011, 'Grazing ungulates select for grasses growing beneath trees in African savannas', Mammalian Biology 76(3), 345-350. https://doi.org/10.1016/j.mambio.2010. 09.003

Turner, M.G., 1989, 'Landscape ecology: The effect of pattern on process', Annual Review of Ecological Systems 20, 171-197. https://doi.org/10.1146/annurev. es.20.110189.001131

Van Aardt, A.C., Codron, D., Theron, E.J. \& Du Preez, P.J., 2020, 'Plant community structure and possible vegetation changes after drought on a granite catena in the Kruger National Park, South Africa', Koedoe 62(2), a1585. https://doi.org/10.4102/ koedoe.v62i2.1585

Van Coller, H., Siebert, F. \& Siebert, S.J., 2013, 'Herbaceous species diversity patterns across various treatments of herbivory and fire along the sodic zone of the Nkuhlu exclosures, Kruger National Park', Koedoe 55(1), 1-6. https://doi.org/10.4102/ koedoe.v55i1.1112

Van Oudtshoorn, F., 2012, Guide to grasses of Southern Africa, 3rd edn., Briza Publications, Pretoria.

Venter, F.J., Scholes, R.J. \& Eckhardt, H.C., 2003, 'The abiotic template and its associated vegetation pattern', in J. Du Toit, H. Biggs \& K.H. Rogers (eds.), The Kruger experience: Ecology and management of savanna heterogeneity, pp. 83-129, Island Press, London.

Wang, J.F., Zhang, T.L. \& Fu, B.J., 2016, 'A measure of spatial stratified heterogeneity', Ecological Indicators 67, 250-256. https://doi.org/10.1016/j.ecolind.2016. 02.052

Weil, R.R. \& Brady, N.C., 2016, The nature and properties of soils, 15th edn., Pearson Education Limited, Harlow.

Whyte, I.J., Van Aarde, R. \& Pimm, S.L., 2003, 'Kruger's elephant population: Its size and consequences for ecosystem heterogeneity', in J.T. Du Toit, K.H. Rogers \& H.C. Biggs (eds.), The Kruger experience: Ecology and management of savanna heterogeneity, pp. 332-348, Island Press, Washington, WA. 